an exceptionally disputatious field. A schism had existed between a rigorous mathematical and the largely qualitative traditional approach since Francis Galton's time. Galton's successor at University College London, Karl Pearson, recalled indeed that, in 1900, when he submitted a paper to its Proceedings, "a resolution of the Council of the Royal Society was conveyed to me, requesting that in future papers, mathematics should be kept apart from biological applications". Pearson was sufficiently incensed to seek Galton's advice as to whether he should resign his fellowship. Darlington, by contrast, evidently relished the contumely.

Some of the biologists in this book scarcely qualify as rebels or heretics. They were firstrate scientists, sure of their data and of the obtuseness of their critics. Notable were Motoo Kimura, who established the principle of neutral evolution, Oswald 'Fess' Avery, who identified DNA as the genetic material, and Howard Temin, who discovered reverse transcriptase. Fine chapters - by James Crow, Kimura's PhD supervisor, by Ute Deichmann and by Daniel Kevles, who clearly knew and admired Temin as man and scientist - do them justice.

Barbara McClintock, on Nathaniel Comfort's evidence, was well liked too, despite portraying herself as swimming ever against the tide. She claimed to have been ostracized and thought "a little mad", when she first presented her observations on linkage groups. In truth, she was respected from the outset. Richard Lewontin in the book's epilogue relates an overheard conversation between two colleagues leaving a lecture: "That is the craziest thing I ever heard", one remarks, "but if Barbara says it, there must be something to it". The historical image diverges, as so often, from the reality.

Can one draw any moral from the sum of these excellent narratives? That the bloodyminded shall inherit the earth? Or perhaps merely the enduring principle of human endeavour, encapsulated by Charles Kettering of General Motors: "First they tell you you're wrong and they can prove it; then they tell you you're right but it isn't important; then they tell you it's important but they knew it all along". Walter Gratzer is in the Randall Division of Cell and Molecular Biophysics, King's College, New Hunt's House, Guy's Campus, London SE1 1UL.

\title{
Bonding as key to hominid origins
}

\section{Primatology meets socio-cultural analysis in a controversial account of human evolution.}

Over the centuries answers to the question of what makes us uniquely human have varied. The Greek philosophers emphasized reason, Enlightenment scholars pointed to our political nature, and nineteenth-century historical evolutionists prioritized our complex social organization. After Charles Darwin and Sigmund Freud, answers became increasingly psychological, and in recent decades attention has turned to the genome and cognition. For the most part, modern social scientists eschew grand debates over human origins, fearful of becoming tarred with the brush of nineteenthcentury social Darwinism.

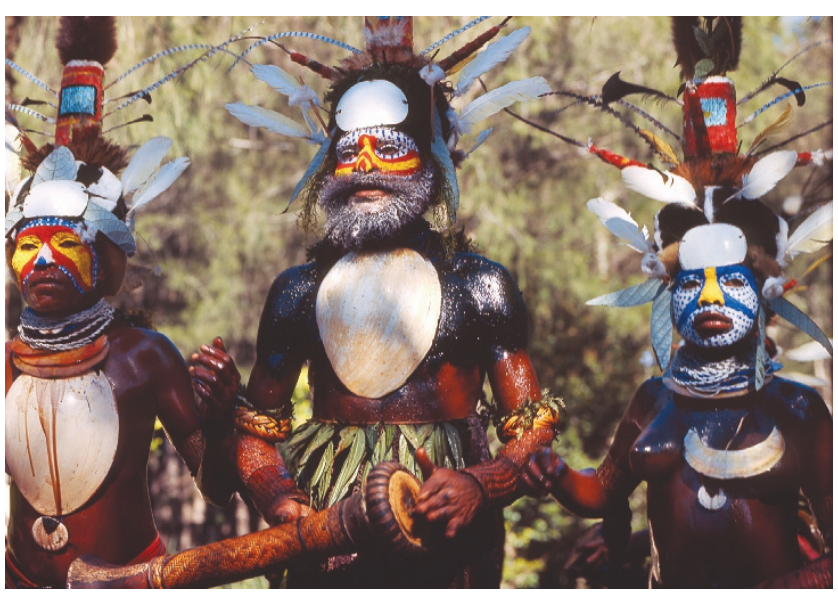

A father in Papua New Guinea displays his marriageable daughters.

de la Parenté about what makes us human. Namely, that men exchange daughters and sisters between kin groups to form alliances. The idea goes back to Tylor's aphorism "marry-out or be killed-out". Placing the story in its phylogenetic context, Chapais radically reorders some of Lévi-Strauss' logic and develops a more fully fledged thesis. For instance, in contrast to Lévi-Strauss' claim, hominids did not invent incest taboos to achieve marital exchange, but inherited them from much deeper animal roots; outmigration of one sex (exogamy) was already in place when the last common ancestor of humans and chimpan-

Primeval Kinship returns to the big questions about ancient society that mesmerized the prominent social theorists of the Victorian era such as Edward Tylor, Lewis Henry Morgan and Friedrich Engels. The author, primatologist Bernard Chapais, offers a powerful and controversial new account of hominid origins. The root of humanity, he argues, lies in pair bonding (the strong affinity that can develop in a breeding couple), the brother-sister tie, and the transfer of females between groups. Imagine a violent chimp-like encounter between two groups of early humans. An attacking dad in one group recognizes his daughter by Bernard Chapais

in the other and thinks twice about killing her baby. Meanwhile the daughter's bonded mate recognizes his sister in the attacking group, and refrains from a counterattack. We might even see some reconciliatory groom-

Primeval Kinship: How Pair-Bonding Gave Birth To Human Society Harvard University Press: 2008. 368 pp. $\$ 39.95, € 25.95, € 30.00$

makers between groups.

A unique feature of human society is the largely peaceful relations between tribes. Chapais reiterates and builds upon the central claim in anthropologist Claude Lévi-Strauss' 1949 classic treatise Les Structures Élémentaires zees stalked the forests.

Chapais' key contribution is to ask how hominids could recognize relatives who had transferred to other groups. He presents evidence from macaques and other primates that mother-child recognition, and cognizance of other mother-child dyads, can exist without the long-term establishment of sexual bonds between mates. Father-offspring recognition, by contrast, requires relatively durable pair bonds. Individuals who can identify a father-child relationship in others can more confidently identify their own siblings. Then, his logic goes, if one sex migrates to other groups, these long-distance sibling links will form the kernel of peaceable intergroup relations. Chapais stands apart from his eminent anthropological forebears, such as Leslie 
White and Robin Fox, all of whom posited that language was the key to exogamy.

Primeval Kinship makes several claims that will upset biological anthropologists. Chapais' model requires that ancestral hominids lived in male-centred kinship groups. Essentially he proposes a nuanced homology between several systems in which males stay in their natal groups and females transfer - in chimps or bonobos and in hunter-gatherers. A common objection to this is that contemporary huntergatherers show variable residence patterns, even cases in which men preferentially reside with their wife's kin.

This for Chapais is irrelevant, as his argument is about origins, not contemporary adaptations to socioecological constraints. Many will contest the assumption of male philopatry, especially adherents to the idea that humans evolved as cooperative breeders. These scholars argue that women's extended post-reproductive lifespans, short intervals between births and the extreme and extended helplessness of our children evolved because of the aid of maternal grandmothers and other kin in rearing children.

Other contentious claims include the irrelevance of infanticide and parental investment in the evolution of pair bonds. The book's treatment of proposed alternatives for pair-bond origins - a pact among individuals to reduce the costs of a physical scramble for mates - is dissatisfying because Chapais fails to consider sexual size dimorphism, brain expansion and changes in life-history traits across the paleoanthropological record. He also argues that food sharing arose from bipedalism, not from male specialization in hunting. Moreover he dismisses language as an important step in our becoming human, a position that will alienate many social scientists. The answer to the perennial question - why did this suite of traits arise only in hominids - is not fully dealt with, despite deft intellectual fencing.

Refreshingly, Chapais does not seek specific selective pressures for every trait. He conceives of evolution occurring under the constraints of prior adaptations and producing novel features from pre-existing parts. He abhors unsubstantiated evolutionary narratives and nimbly marshals evidence from primatological studies to sociocultural analyses to support his case. In the end, his book offers us one more scenario of our human trajectory, but it is a scholarly one. Chapais' thesis urges us to consider very carefully why humans are so different.

Monique Borgerhoff Mulder is professor at the Department of Anthropology, Graduate Group in Ecology, and Center for Population Biology at the University of California, Davis, 1Shields Avenue, Davis, CA 95616. She is co-author of Conservation: Linking Ecology, Economics and Culture.

\section{Novel alchemy}

\author{
The Sun and Moon Corrupted \\ by Philip Ball \\ Portobello Books: 2008. 423 pp. £10.99
}

How do you write a novel about science? Many people do it badly, but with The Sun and Moon Corrupted, Philip Ball succeeds at his first attempt. Six steps lead to a good read, and Ball has aced them all (almost).

First, the book must have some science in it. Every tribe likes to see its rituals described. Ball relays the over-hearty greetings that anxious newcomers call out at scientific conferences. He mentions the nutty letters that serious researchers get from 'mad' outsiders: "To my last letter I have not received an answer... You have to send all three papers for composition... Any day of delaying its announcement costs milliards of dollars."

Second, it needs more than science. Recounting surface traits is fun, but on its own produces a standard academic novel in which nothing of depth lingers after the reader's delight at self-recognition has passed. A lesson in abject failure is provided by Tom Stoppard. In his play Hapgood, Stoppard pairs ambiguities in quantum mechanics with those in the British spy world. The play fails because there is no inherent link between quantum quirks and secret intelligence. Stoppard could have stripped the science without affecting the plot.

Ball doesn't throw in his science as an optional extra - it infuses his descriptions. Where laundry blows in the wind on the balconies of abandoned high-rise blocks, he notes with a chemist's eye that "already the dyes were burning, breaking up, and fading, the brightest and cheapest first, in the sun's strong glare." On a deeper level, his plot - of how a once-sensible researcher becomes a 'nutty' outsider who believes in perpetual motion - depends on science for its essence.

The third step is not to forget people. Without believable characters you have not a novel but a disquisition, chunkily hidden under dialogue. Bertrand Russell was an eloquent writer of non-fiction and an important logician, but his fiction was as convincing as Rupert Murdoch talking about ethics. Ball is far better. Karel Neder, the researcher he tracks in The Sun and Moon Corrupted, is believable. We meet him in his early teens as he discovers the beauties of science. He thrills at finding the first friends he can share his excitement with at university; and realizes that although he's a good student, others are better. He wonders how he will ever compete with them in a research career.

Step four, weave a story. Because science is taught as a sequence of inevitable breakthroughs, science novelists often copy that structure. Indirect approaches are more compelling. Ball starts his novel with a corker of a mystery. An intense young woman, Lena, walks in an abandoned city. She eyes the laundry still hanging, and observes rows of shoes in the town's kindergarten, all neatly in order, with a name painted inside each one. We wonder why the town has been left, and why she is there.

Step five is to be rational. It's a treat to follow Lena's quest. She's a new journalist, trying to make a living as a freelancer, but her heart is not in it. More important is her relationship with her father, a physicist at a British university. She can't bear to disappoint him, yet his smug rationality gives her little space to breathe. When Lena hears of the now elderly Neder's work, she realizes that his talk of perpetual motion machines is nonsense, and wants to know how he parted from the scientific mainstream. She reconstructs

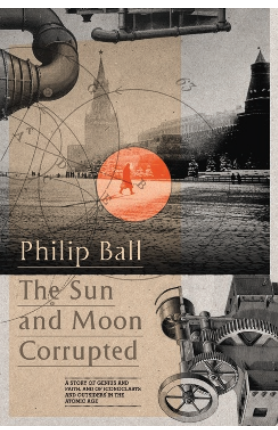
his path: from his escape from his native Hungary to success in the United States, before returning to Europe, where he exists at the fringes of academia. The levels in Ball's plot hold together like a musical chord. Will understanding Neder's life allow Lena to understand both her father and herself?

The sixth lesson is to avoid being too rational. Ball's writing is hyper-realistic, and he gives accounts of scientific conferences, journalists and secret police, yet still conveys a feeling that something else is going on, something important that lurks below our consciousness. The abandoned city is permeated with the mood from the Bible's book of Revelation: "And the city had no need of the sun, neither of the moon, to shine in it." As the narrator talks about dye sequences and Lena tries to grasp what drove Neder, there are deeper, almost alchemical, forces at work.

David Bodanis is the author of Passionate Minds: The Great Scientific Affair. 